\title{
Using Pomegranate Peel and Date Pit Activated Carbon for the Removal of Cadmium and Lead Ions from Aqueous Solution
}

\author{
Wedad A. Al-Onazi $\mathbb{D D}^{1}{ }^{1}$ Mohamed H.H. Ali $\mathbb{D}^{2},{ }^{2}$ and Tahani Al-Garni $\mathbb{D}^{1}$ \\ ${ }^{1}$ Department of Chemistry, College of Science, King Saud University, Riyadh, Saudi Arabia \\ ${ }^{2}$ National Institute of Oceanography \& Fisheries, Cairo, Egypt \\ Correspondence should be addressed to Wedad A. Al-Onazi; walonazi@ksu.edu.sa
}

Received 21 January 2021; Revised 24 June 2021; Accepted 23 August 2021; Published 6 September 2021

Academic Editor: Shafaqat Ali

Copyright (c) 2021 Wedad A. Al-Onazi et al. This is an open access article distributed under the Creative Commons Attribution License, which permits unrestricted use, distribution, and reproduction in any medium, provided the original work is properly cited.

\begin{abstract}
Some agricultural byproducts are useful for solving wastewater pollution problems. These byproducts are of low cost and are effective and ecofriendly. The study aim was to investigate the possibility of using pomegranate peel (PP) and date pit (DP) activated carbon (PPAC and DPAC, respectively) as sorbents to remove $\mathrm{Cd}(\mathrm{II})$ and $\mathrm{Pb}$ (II) from aqueous solutions. Agricultural wastes of DPs and PPs were subjected to carbonization and chemical activation with $\mathrm{H}_{3} \mathrm{PO}_{4}(60 \%)$ and $\mathrm{ZnCl}_{2}$ and used as adsorbents to remove $\mathrm{Cd}(\mathrm{II})$ and $\mathrm{Pb}(\mathrm{II})$ from their aqueous solutions. The physical characterizations of PPAC and DPAC, including determination of surface area, scanning electron microscopy, energy-dispersive X-ray spectroscopy, and Fouriertransform infrared spectroscopy, were performed. The following factors affected adsorption: solution $\mathrm{pH}$, adsorbent dosage, initial metal ion concentration, and contact time. These factors were studied to identify the optimal adsorption conditions. The results showed that the maximum adsorptions of $\mathrm{Cd}(\mathrm{II})$ and $\mathrm{Pb}$ (II) were achieved at $\mathrm{pH}$ ranging from 6 to $6.5,90$ min contact time, and $0.5 \mathrm{~g} / \mathrm{L}$ for PPAC and $1 \mathrm{~g} / \mathrm{L}$ for DPAC dosage. Furthermore, the adsorption efficiencies for both $\mathrm{Pb}$ (II) and Cd(II) were higher for PPAC than for DPAC. However, the recorded $Q_{\max }$ values for PPAC were 68.6 and $53.8 \mathrm{mg} / \mathrm{g}$ for Pb(II) and Cd(II) and for DPAC were 34.18 and $32.90 \mathrm{mg} / \mathrm{g}$ for $\mathrm{Pb}(\mathrm{II})$ and $\mathrm{Cd}(\mathrm{II})$, respectively. The Langmuir isotherm model fit the adsorption data better than the Freundlich model. Kinetically, the adsorption reaction followed a pseudo-second-order reaction model, with $q_{\mathrm{e}}$ ranging from 12.0 to $22.37 \mathrm{mg} / \mathrm{g}$ and an $R^{2}$ value of 0.99 .
\end{abstract}

\section{Introduction}

The recent notable deterioration of water quality mainly due to urbanization, anthropogenic wastes, increasing population growth, progressive industrialization, and unsafe water resources utilization [1] has led to water resources contaminated with different pollutants (e.g., toxic metal ions, pesticides, agricultural fertilizers). The progressively increasing amounts of different pollutants have caused alarm about water quality [2]. Minimization and control of water pollution problems have become an urgent necessity, and great efforts have been made to develop ecofriendly, lowcost, and effective techniques to remove pollutants from aquatic environments [3]. Several technological processes have been developed by different researchers, including photo-oxidation $[4,5]$, advanced oxidation [6, 7], and bioremediation using biomasses [8]. These processes have certain disadvantages, mainly high operational costs and maintenance. In addition, they have some complicated steps and may generate toxic byproducts of their own [9].

Recently, adsorption processes using activated carbon from agricultural wastes, sludge, or other carbonaceous precursors have been used because they are ecofriendly, are of low cost, and enable use of simple procedures. This technique has been used for removing various contaminants from water, including metals and dyes [10-13]. Currently, adsorption reactions are considered the most ecofriendly, low-cost, selective, and efficient treatment technique for removing heavy metals and other organic pollutants from wastewater $[14,15]$. This technique involves surface 
adsorption in which adsorbate particles are attached and held to the adsorbent surface until reaching equilibrium between free and bound molecules in the carrier liquid or gas [16].

Recently, agricultural wastes are used to produce porous activated carbon (AC), which is considered one of the most popular and widely used adsorbents for the removal of heavy metal ions from wastewater. Various agricultural wastes are found in huge quantities, which provide the advantages for this method such as high availability, low cost, high adsorption efficiency, and high removal capacity [17]. These wastes include orange peel [12], rice husks [18], coconut shells [19], Kiwi, mandarin, and banana peels [20, 21], pomegranate peel modified with zerovalent iron nanoparticles [22], pomegranate peel [23-25], and date pits [26-28]. Some modified natural wastes were used as substrates to remove heavy metals.

In this study, pomegranate peels (PPs) and date pits (DPs) were used because they are the most locally available precursors in Saudi Arabia for the preparation of AC materials. $\mathrm{PP}$ is a byproduct of tanneries and pomegranate juice industries [29]. Additionally, DPs are common commercial agricultural wastes in the palm food industry [30]. Hence, DPs and PPs are suitable for AC preparation because of their good natural structure, renewable sources, low cost, and low ash content [31]. Therefore, AC from PPs (PPAC) and DPs (DPAC), which are characterized by large surface area, high micropore volume, and extremely high adsorption efficiency, potentially can be used to prepare efficient sorbents for the removal of pollutants from water. Therefore, the prepared PPAC and DPAC adsorbents are considered excellent novel adsorbents because of their low cost and highly effective substrates. However, the hydrothermal chemical activation processing modified the adsorbents' characteristics that made them have great abilities to remove toxic metals $(\mathrm{Cu}(\mathrm{II})$ and $\mathrm{Ni}(\mathrm{II}))$ and $\mathrm{Pb}(\mathrm{II})$ in a single-step process from aqueous solutions due to their high surface area, enlarged pore size, and existence of several different functional groups onto their surfaces.

The study aim was to investigate the possibility of using PPAC and DPAC as sorbents to remove $\mathrm{Cd}(\mathrm{II})$ and $\mathrm{Pb}(\mathrm{II})$ from aqueous solutions. Some factors that affect the adsorption process, such as solution $\mathrm{pH}$, sorbent dose, duration time, and initial metal concentrations, were studied. Furthermore, different kinetic and isotherm models for $\mathrm{Pb}(\mathrm{II})$ and $\mathrm{Cd}(\mathrm{II})$ adsorption were investigated.

\section{Materials and Methods}

2.1. Chemicals and Reagents. Lead nitrate, cadmium nitrate, sodium hydroxide, and hydrochloric acid used in this study were of analytical grade and purchased from Sigma (Germany). $\mathrm{Cd}(\mathrm{II})$ and $\mathrm{Pb}(\mathrm{II})$ stock solutions of $1000 \mathrm{mg} / \mathrm{L}$ were prepared by dissolving $\mathrm{Pb}\left(\mathrm{NO}_{3}\right)_{2}$ and $\mathrm{Cd}\left(\mathrm{NO}_{3}\right)_{2}$ in deionized water. For each experiment, serial dilutions were prepared using deionized water to obtain the required concentrations. The $\mathrm{pH}$ of each solution was adjusted using $0.1 \mathrm{~N} \mathrm{HCl}$ or $1 \mathrm{~N} \mathrm{NaOH}$ to the required experimental value.
2.2. Activated Carbon (AC) Preparation. Date pit (DP) and pomegranate peel (PP) wastes were collected from local markets in Riyadh City, Saudi Arabia. In the laboratory, the DPs and PPs were washed well with hot deionized water and dried in an open-air oven (Genlab-Mino 50) at $105^{\circ} \mathrm{C}$ for $24 \mathrm{hr}$. After reaching constant weight, the DPs and PPs were crushed and ground in a mill to a fine powder and then sieved through progressively finer sieves to yield a final particle size of $<120 \mu \mathrm{m}$. AC from DPs (DPAC) and PPs (PPAC) was prepared by soaking dry fine particles of DPs and $\mathrm{PPs}$ with $\mathrm{H}_{3} \mathrm{PO}_{4}(60 \%)$ and $\mathrm{ZnCl}_{2}(50 \mathrm{wt} \%)$ at a ratio $1: 1$ by volume for $24 \mathrm{hr}$ to chemically activate them. Then, the mixtures were dried in an oven at $105^{\circ} \mathrm{C}$. Finally, carbonization was performed in a muffle furnace (Nabertherm L5) at $500^{\circ} \mathrm{C}$ for $60-70 \mathrm{~min}$ in the absence of air.

2.3. Characterizations. The surface area $\left(\mathrm{S}_{\mathrm{BET}}\right)$ of the prepared AC was estimated by using the Brunauer-EmmettTeller method $\left(\mathrm{S}_{\mathrm{BET}}\right)$ using a Coulter SA3100 instrument with outgas for $15 \mathrm{~min}$ at $150^{\circ} \mathrm{C}$. A scanning electron microscope (model: JEM-2100-JEOL; Tokyo, Japan) was used for scanning electron microscopy (SEM) and energy-dispersive X-ray (EDX) measurements. Fourier-transform infrared spectroscopy (FTIR) analysis was performed to identify the different principal functional groups using a spectrometer (6700 FTIR; Nicolet, America).

2.4. Batch Adsorption Study. A series of serial standard solutions was prepared by dissolving $\mathrm{Pb}\left(\mathrm{NO}_{3}\right)_{2}$ and $\mathrm{Cd}\left(\mathrm{NO}_{3}\right)_{2}$ salts in deionized water. The effect of solution $\mathrm{pH}$, contact time, initial metals' concentrations, and sorbent dosage was investigated as important factors that could affect the adsorption process. A $100 \mathrm{ml}$ aliquot of the metal ions mixture was used for each experiment under fixed conditions. All experiments were performed at room temperature between 22 and $25^{\circ} \mathrm{C}$ and a fixed shaking speed of $250 \mathrm{rpm}$. Then, samples were centrifuged at $10,000 \mathrm{rpm}$ for $10 \mathrm{~min}$, the solution was withdrawn, and the concentrations of $\mathrm{Pb}$ (II) and $\mathrm{Cd}(\mathrm{II})$ were measured by using inductively coupled plasma-atomic emission spectroscopy (ICP-AES; Agilent 5800$)$. The metal adsorption capacity $\left(q_{\mathrm{e}}, \mathrm{mg} / \mathrm{g}\right)$ and removal efficiency $(\mathrm{R} \%)$ are calculated as follows:

$$
\begin{array}{r}
q_{e}=\frac{\left(C_{0}-C_{e}\right) \times V}{M}, \\
R \%=\frac{\left(C_{o}-C_{e}\right) \times 100}{C_{e}},
\end{array}
$$

where $q_{e}$ is the equilibrium metal concentration; $C_{0}$ and $C_{e}$ are the initial and final metal ion concentrations in solution $(\mathrm{mg} / \mathrm{L})$, respectively; $V$ is the volume of metal ions in solution (L); and $M$ is the sorbent mass ( $\mathrm{g}$ ).

\section{Results and Discussion}

3.1. Characterization. SEM is useful for describing the porous heterogeneity and surface morphological structures of the adsorbents. Figures 1(a) and 1(b) show the SEM 


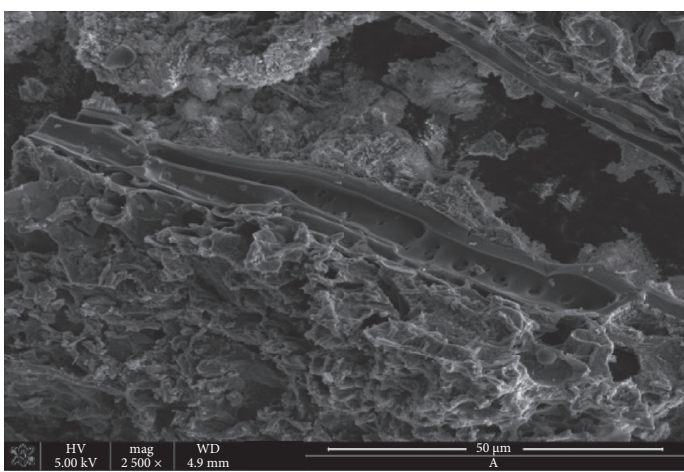

(a)

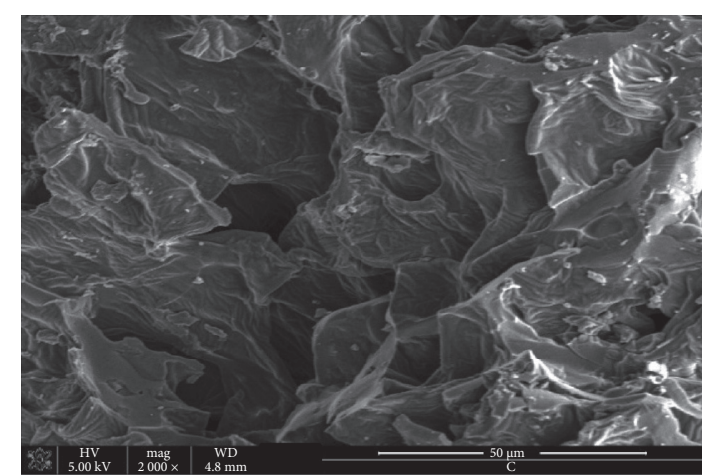

(b)

Figure 1: Scanning electron microscopy (SEM) images: (a) DPAC sorbent and (b) PPAC sorbent.

micrographs for DPAC and PPAC at different magnifications. The SEM micrographs showed that both sorbents had amorphous irregular surface structures. A smoother texture, a more porous surface, and a lower particle size were observed for PPAC than for DPAC, which have been shown to be associated with the compositional nature of the initial precursor and lignin content [32]. However, pomegranate peel contains a higher level of lignin than date pits, and therefore, the morphological structures of PPAC and DPAC are different after carbonization and activation [33, 34]. EDX spectroscopy was performed to determine the elemental composition of DPAC and PPAC (Figures 2(a) and 2(b)). The EDX spectra showed the presence of two major peaks of oxygen and carbon with abundance percentages of $52.48 \%$ and $25.43 \%$ in the DPAC adsorbent, respectively, while the corresponding abundance ratio were $52.2 \%$ and $24.2 \%$ in the PPAC adsorbent. In general, the high percentages of oxygen and carbon are closely related to the nature of the PPs and DPs used [35]. Additionally, some minor peaks were detected in the PPAC adsorbent, which belong to $\mathrm{Mg}(5.1 \%), \mathrm{Si}$ (3.1\%), and $\mathrm{K}(3 \%)$. A slightly higher difference was observed in the minor peaks that detected in DPAC than PPAC, and the minor peaks are $\mathrm{Si}(5.5 \%), \mathrm{Mg}(4.2 \%), \mathrm{K}(2.1 \%)$, and $S(1.1 \%)$.

FTIR spectroscopy was used to identify and characterize different functional groups present on the surface of the PPAC and DPAC sorbents. Table 1 and Figure 3 show the different function groups existing on the surface of the two sorbents. Before the adsorption process, a narrow band at $3950 \mathrm{~cm}^{-1}$ was observed on the surface of PPAC that attributed to the $-\mathrm{OH}$ stretching of water molecules; this band was shifted after adsorption to $3949 \mathrm{~cm}^{-1}$, indicating the interaction between metal ions adsorbed onto the active sites. A broad band at $3600-3150 \mathrm{~cm}^{-1}$ was attributed to the carboxylic acid $-\mathrm{OH}$ stretching in lignin and cellulose [36], asymmetric stretching $\mathrm{O}=\mathrm{C}=\mathrm{O}$ of the $\mathrm{CO}_{2}$ group appeared at $2370 \mathrm{~cm}^{-1}$. A carboxyl peak was observed at $1650 \mathrm{~cm}^{-1}$, and a band at $565 \mathrm{~cm}^{-1}$ was attributed to out-of-plane C-H vibrations $[37,38]$. After the adsorption process, all these bands were significantly shifted to other wave numbers, indicating successful binding of metal ions with different function groups onto the surface of PPAC (Table 1). However, five peaks were observed for DPAC before adsorption at $3460,2935,1750,1470$, and $1025 \mathrm{~cm}-1$ and were attributed to carboxylic acid - $\mathrm{OH}$ stretching, $\mathrm{C}-\mathrm{H}$ symmetric vibrations, nonionic carboxyl groups $(\mathrm{COOH}), \mathrm{C}-\mathrm{H}$ bending in cellulose, and $\mathrm{C}-\mathrm{O}$ stretching in the alcoholic hydroxyl group, respectively [39]. These bands are significantly shifting to $3451,2927,1741,1461$, and $1022 \mathrm{~cm}^{-1}$ after adsorption of metal ions (Table 1). FTIR spectroscopy indicated the presence of oxygen-containing functional groups (e.g., $-\mathrm{OH},-\mathrm{COOH},-\mathrm{O}=\mathrm{C}=\mathrm{O}$, and $-\mathrm{C}-\mathrm{O}$ ) onto the surface of PPAC and DPAC adsorbents, and this indicates that the main mechanism of metal ions adsorption is the typical oxidation process due to the presence of functional groups containing oxygen, leading to enhancing the adsorption of heavy metals [40].

Determination of the specific surface area is most important for showing the capacity of adsorption onto an $\mathrm{AC}$ sorbent. Table 2 and Figure 4 show the calculated values of $\mathrm{S}_{\mathrm{BET}}$ for DPAC and PPAC. Compared with DPAC $\left(278.18 \mathrm{~m}^{2} / \mathrm{g}\right)$, PPAC has a higher $\mathrm{S}_{\mathrm{BET}}\left(350.22 \mathrm{~m}^{2} / \mathrm{g}\right)$. These $\mathrm{S}_{\mathrm{BET}}$ values were less than those obtained by Abedi et al. [41] who reported $887 \mathrm{~m}^{2} / \mathrm{g}$ for the surface area of AC from PP modified by iron and by Manel et al. [42] who recorded $1354 \mathrm{~m}^{2} / \mathrm{g}$ for PP activated thermally at $800^{\circ} \mathrm{C}$. The maximum $\mathrm{S}_{\mathrm{BET}}$ for date seeds was previously found to be $860 \mathrm{~m}^{2} /$ $\mathrm{g}$ after thermal activation at $800^{\circ} \mathrm{C}[43]$.

\subsection{Batch Biosorption Experiments}

3.2.1. Effect of $p H$. The adsorption process was greatly affected by the $\mathrm{pH}$ values of aqueous solutions of metal ions since it not only controls active sites dissociation on the sorbent surface but also governs the ionization degree and metals speciation in the solution [41]. To study the effect of $\mathrm{pH}$ values on the adsorption efficiency of DPAC and PPAC, a $\mathrm{pH}$ range of 2.5-7 was selected to show the removal capacity of $\mathrm{Cd}(\mathrm{II})$ and $\mathrm{Pb}(\mathrm{II})$ onto both adsorbents' surface at a $100 \mathrm{mg} / \mathrm{L}$ metal concentration for a 90-min contact time and $0.5 \mathrm{~g} / \mathrm{L} \mathrm{PPAC}$ and $1 \mathrm{~g} / \mathrm{L} \mathrm{DPAC}$ adsorbent doses (Figure 5). 


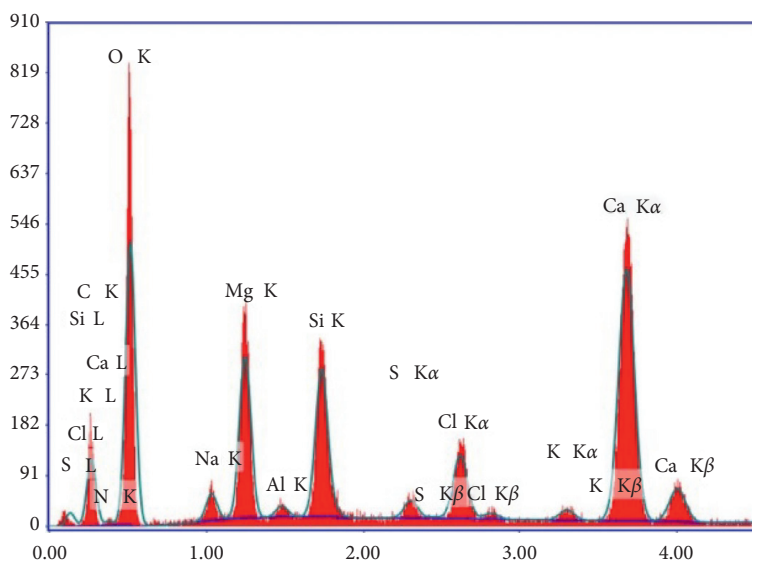

Lsec: 30.00 Cnts $0.000 \mathrm{keV}$ Det: Octane Pro Det

(a)

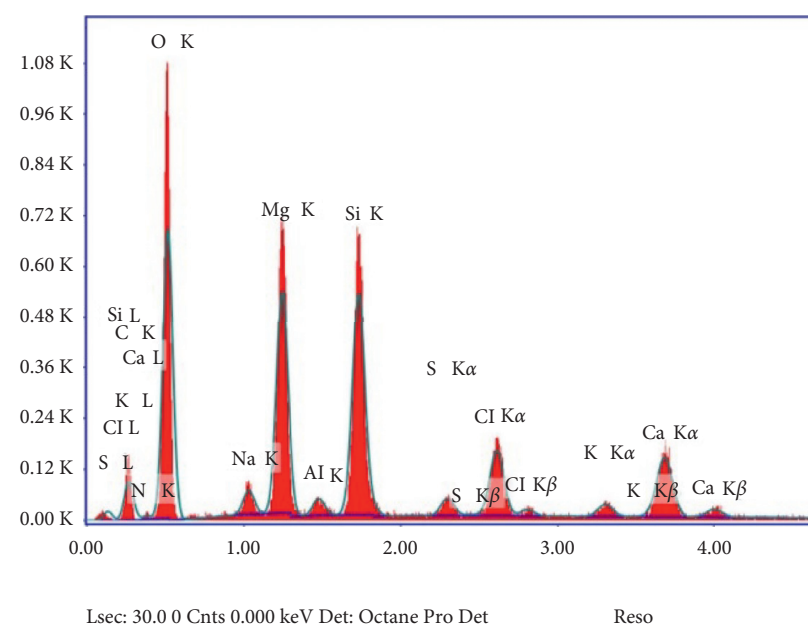

(b)

Figure 2: EDX spectra: (a) DPAC adsorbent and (b) PPAC adsorbent.

TABLE 1: The main functional groups detected on the surfaces of DPAC and PPAC.

\begin{tabular}{|c|c|c|c|}
\hline \multicolumn{2}{|c|}{ Frequency $\left(\mathrm{cm}^{-1}\right)$} & DPAC & PPAC \\
\hline Before adsorption & After adsorption & Band function groups & Function groups \\
\hline 3956 & 3949 & $*$ & -OH stretching \\
\hline $3600-3150$ & $3590-3142$ & $*$ & Carboxylic acid $-\mathrm{OH}$ stretch \\
\hline $3460-3350$ & $3451-3339$ & Carboxylic acid $-\mathrm{OH}$ stretch & $*$ \\
\hline 2935 & 2927 & $\mathrm{C}-\mathrm{H}$ vibrations & $*$ \\
\hline 2369 & 2391 & $*$ & $\mathrm{O}=\mathrm{C}=\mathrm{O}$ asymmetric stretch $\left(\mathrm{CO}_{2}\right)$ \\
\hline 1750 & 1741 & Carboxylic $\mathrm{COOH}$ stretching & $*$ \\
\hline 1654 & 1659 & $*$ & Carboxylic COOH stretching \\
\hline $1470-1269$ & $1461-1260$ & $\mathrm{C}-\mathrm{H}$ bending & $*$ \\
\hline 1025 & 1022 & $\mathrm{C}-\mathrm{O}$ stretching of alcoholic $\mathrm{OH}$ & $*$ \\
\hline 565 & 561 & $*$ & $\mathrm{C}-\mathrm{H}$ vibration \\
\hline
\end{tabular}

${ }^{*}$ Not available.

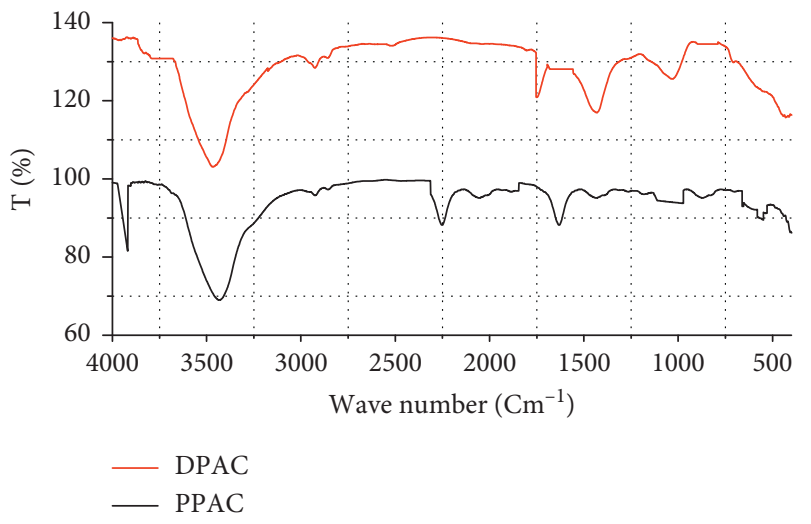

FIGURE 3: FTIR spectrum of adsorbents: DPAC (red line) and PPAC (black line).

TABLE 2: The specific surface areas, radii, and pore volumes obtained for DPAC and PPAC.

\begin{tabular}{lccc}
\hline Sorbent & $\mathrm{S}_{\mathrm{BET}}\left(\mathrm{m}^{2} \mathrm{~g}^{-1}\right)$ & $r(\mathrm{~nm})$ & $V_{P}^{\text {total }}\left(\mathrm{cm}^{3} \mathrm{~g}^{-1}\right)$ \\
\hline DPAC & 278.185 & 53.94 & 0.485 \\
PPAC & 350.22 & 31.17 & 0.383 \\
\hline
\end{tabular}



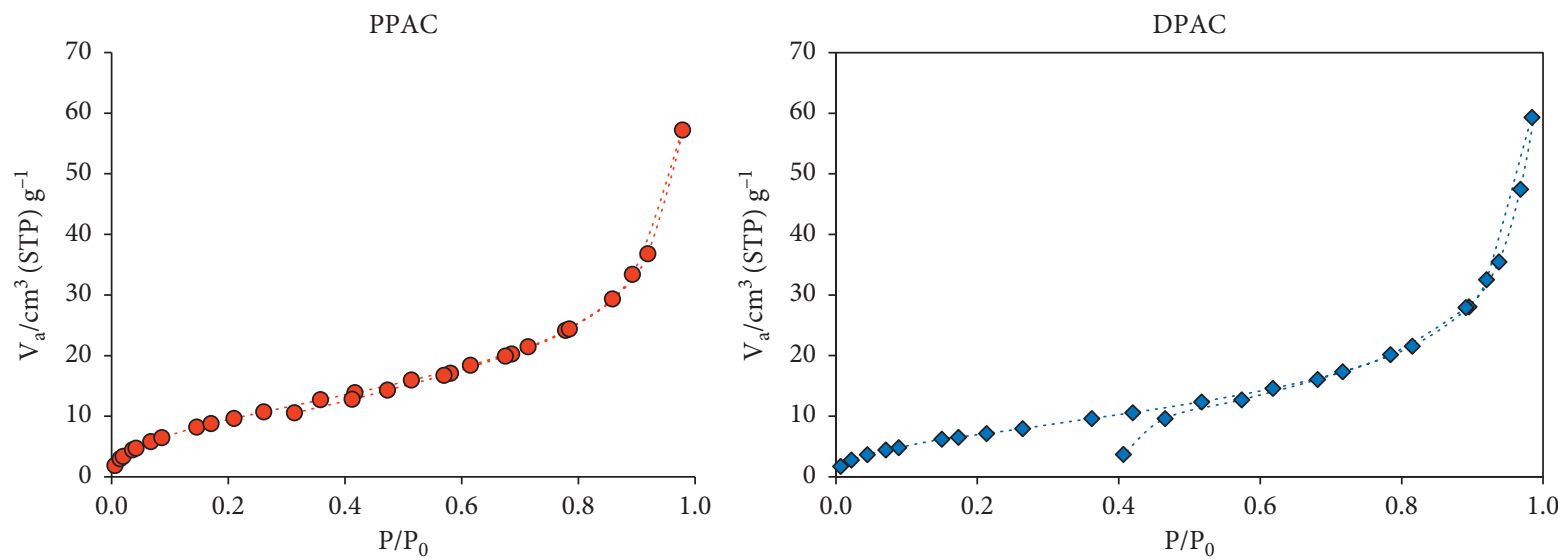

FIGURE 4: $\mathrm{N}_{2}$ sorption-desorption isotherms of prepared nanocomposites.
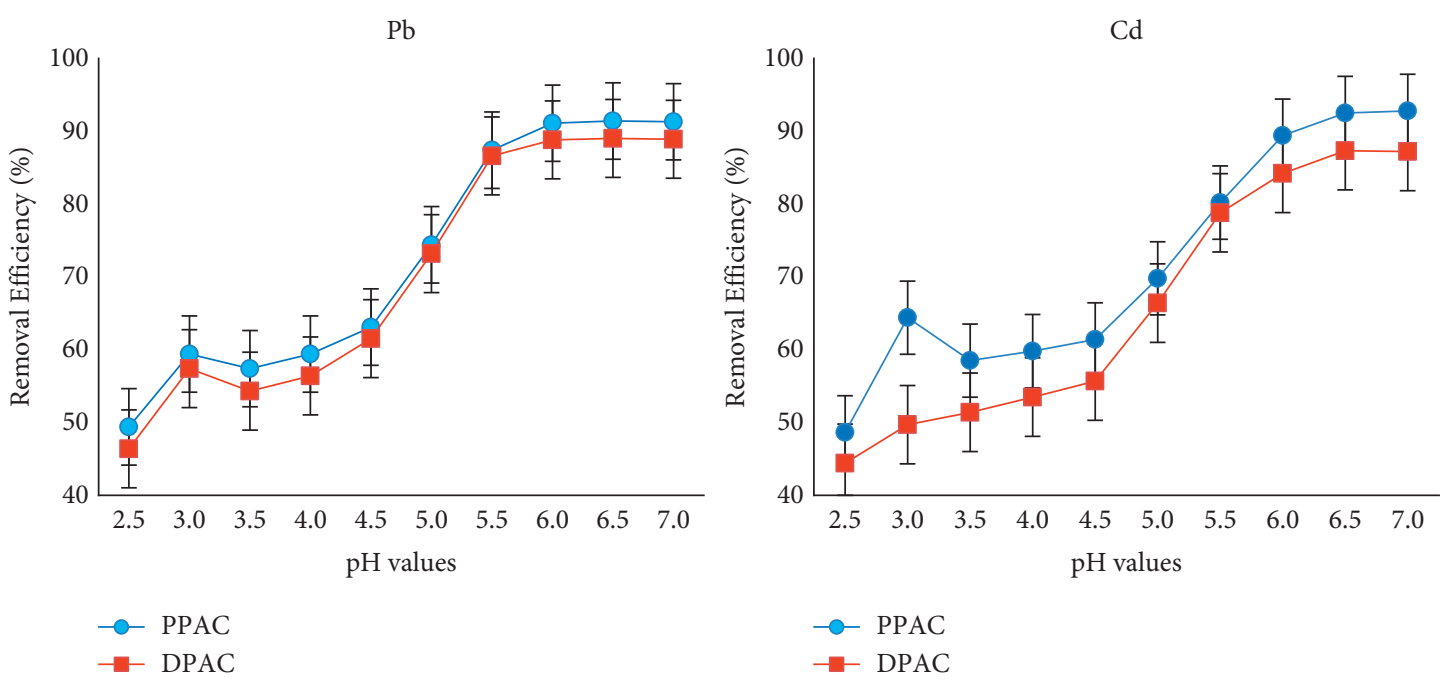

Figure 5: Effect of $\mathrm{pH}$ on the adsorption efficiencies of $\mathrm{Pb}(\mathrm{II})$ and $\mathrm{Cd}(\mathrm{II})$ on the surfaces of DPAC and PPAC (metal concentration $=100 \mathrm{mg} / \mathrm{L}$, contact time $=90 \mathrm{~min}$, dose of $\mathrm{DPAC}=1 \mathrm{~g} / \mathrm{L}$, and dose of PPAC $=0.5 \mathrm{~g} / \mathrm{L})$.

We observed an obvious increase in removal efficiency by gradually increasing $\mathrm{pH}$ values. The maximum removal ratio for $\mathrm{Pb}(\mathrm{II})$ was $91.1 \%$ for PPAC and $88.8 \%$ for DPAC at $\mathrm{pH}$ 6. The maximum removal ratio for $\mathrm{Cd}(\mathrm{II})$ was $92.5 \%$ for PPAC and $87.3 \%$ for DPAC at pH 6.5 (Figure 5). A remarkable lowering in removal efficiency was observed at very low $\mathrm{pH}$ values $(1-3)$ because of the high protonation process, which causes the formation of protonated hydrous oxides besides generating the positive charges that accumulate on the adsorbent surface layer, leading to electrostatic repulsion between positive metal ions and the positively charged adsorbent surface as shown in the following equations:

$$
\begin{aligned}
& \equiv \mathrm{Cd}-\mathrm{OH}+\mathrm{H}^{+} \leftarrow \longrightarrow \equiv \mathrm{Cd}-\mathrm{OH}_{2}^{+} \\
& \equiv \mathrm{Pb}-\mathrm{OH}+\mathrm{H}^{+} \leftarrow \longrightarrow \equiv \mathrm{Pb}-\mathrm{OH}_{2}^{+}
\end{aligned}
$$

With increasing $\mathrm{pH}$, the hydrous oxides were deprotonated in addition to the decrease of the positive charges, so the sorption sites become available and the adsorption of metal ions increases $[44,45]$, and at very high $\mathrm{pH}$ values $(>8)$, the metal ions precipitated (Figure 6).

$$
\begin{aligned}
& \equiv \mathrm{Cd}-\mathrm{OH}+\mathrm{OH}^{-} \leftarrow \longrightarrow \equiv \mathrm{Cd}-\mathrm{O}^{-}+\mathrm{H}_{2} \mathrm{O} \\
& \equiv \mathrm{Pb}-\mathrm{OH}+\mathrm{OH}^{-} \leftarrow \longrightarrow \equiv \mathrm{Pb}-\mathrm{O}^{-}+\mathrm{H}_{2} \mathrm{O}
\end{aligned}
$$

Analysis of variance (ANOVA) revealed an insignificant difference in the removal efficiencies between the two adsorbents $(r=0.08$ at $P>0.11)$.

3.2.2. Effect of Contact Time. The effect of contact time on the adsorption of $\mathrm{Pb}(\mathrm{II})$ and $\mathrm{Cd}(\mathrm{II})$ onto the surfaces of DPAC and PPAC was studied over the range of 15-150 min (Figure 7). The adsorption rates notably increased in the beginning of the reaction during the first 30-45 min because of the high availability of active sites on the adsorbents' surfaces. But then the reaction slowed down until reaching equilibrium after $90 \mathrm{~min}$, with a maximum adsorption capacity of $91.1 \%$ and $91.2 \%$ for $\mathrm{Pb}(\mathrm{II})$ and $91.1 \%$ and $91.3 \%$ for 


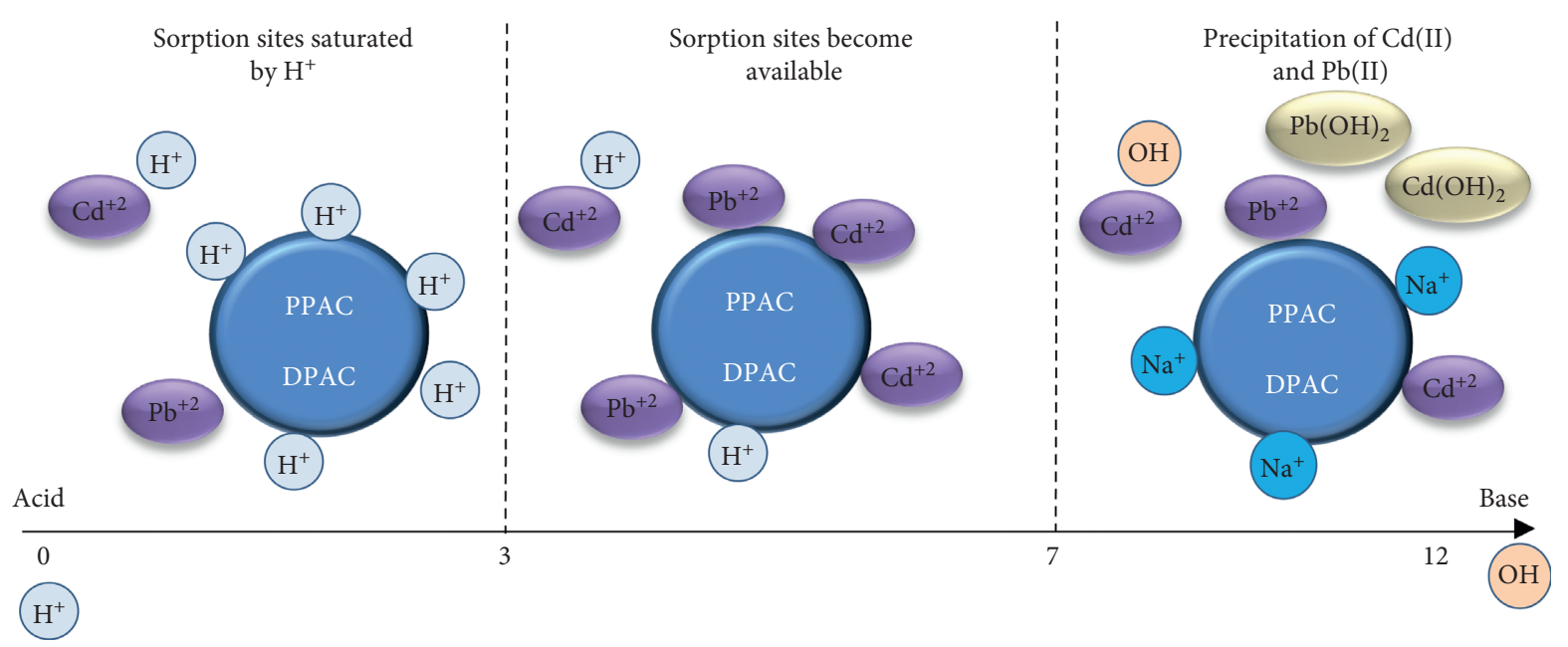

FIgURE 6: Effect of $\mathrm{pH}$ on the adsorption of $\mathrm{Cd}(\mathrm{II})$ and $\mathrm{Pb}(\mathrm{II})$ onto PPAC and DPAC at different $\mathrm{pH}$ values.
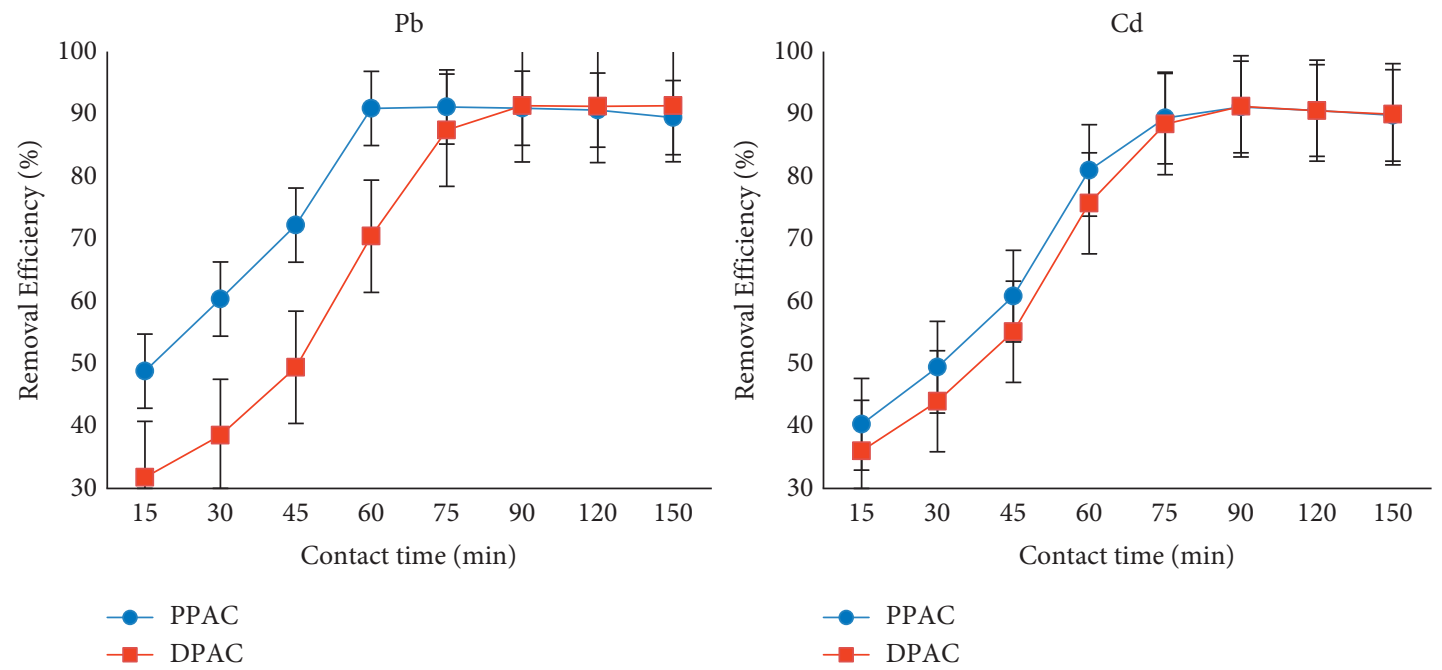

FIGURE 7: Effect of contact time on the adsorption of $\mathrm{Pb}(\mathrm{II})$ and $\mathrm{Cd}(\mathrm{II})$ onto the surfaces of DPAC and PPAC (pH $=6$, metal concentration $=100 \mathrm{mg} / \mathrm{L}, \mathrm{DPAC}$ dose $=1 \mathrm{~g} / \mathrm{L}$, and PPAC dose $=0.5 \mathrm{~g} / \mathrm{L})$.

Cd(II) on the surfaces of DPAC and PPAC, respectively. ANOVA showed no significant difference in the removal efficiencies between the adsorbents $(r=0.15, P>0.20)$, but there was a significant difference in time intervals $(r=0.82$, $P<0.05)$ between the adsorbents.

Our recent data were consistent with the Hilal et al. [46] data showing $75 \mathrm{~min}$ as the optimum duration for the adsorption of $\mathrm{Cd}(\mathrm{II})$ and $\mathrm{Cu}$ (II) onto the surface of DPAC. In addition, Salmani et al. [44] found that the optimum equilibrium time was $90 \mathrm{~min}$ for the adsorption of $\mathrm{Pb}$ (II) onto modified PPAC (Table 3).

3.2.3. Effect of Dose. To detect the optimum amount of adsorbent required for the maximum adsorption efficiency, the adsorbent dose was investigated by varying the quantities of both adsorbents from 0.1 to $1 \mathrm{~g} / \mathrm{L}$ at $\mathrm{pH} 6$, initial metal ion concentration of $100 \mathrm{mg} / \mathrm{L}$, and a $90 \mathrm{~min}$ contact time (Figure 8). The results showed a gradual increase in adsorption efficiency by increasing the adsorbent mass because of the great availability of active exchange sites onto the adsorbents' surfaces. The removal capacity reached a maximum of $92.3 \%$ for both $\mathrm{Pb}(\mathrm{II})$ and $\mathrm{Cd}(\mathrm{II})$ at $0.5 \mathrm{~g} / \mathrm{L}$ of PPAC and remained steady. The removal capacity reached a maximum of $91 \%$ for $\mathrm{Pb}(\mathrm{II})$ and $\mathrm{Cd}(\mathrm{II})$ at $1 \mathrm{~g} / \mathrm{L}$ of DPAC. ANOVA showed a slightly significant difference in adsorption efficiency between DPAC and PPAC $(r=0.41$, $P<0.05)$. Moghadam et al. [43] and Salmani et al. [44] found that $1 \mathrm{~g} / \mathrm{L}$ was the optimum dose of PPAC for the maximum removal of $\mathrm{Fe}(\mathrm{II})$ and $\mathrm{Pb}$ (II) from their aqueous solution. AlBalushi et al. [47] reported an optimum dose of $1 \mathrm{~g} / \mathrm{L}$ for DPAC to reach the maximum removal efficiency for methylene blue dye from aqueous solutions.

3.2.4. Effect of Initial Metal Concentration. The effect of initial $\mathrm{Pb}$ (II) and $\mathrm{Cd}$ (II) concentrations on the efficiency of adsorption was investigated over a concentration range from 10 to $100 \mathrm{mg} / \mathrm{L}$ (Figure 9). The results showed increasing removal rates with increasing $\mathrm{Pb}(\mathrm{II})$ and $\mathrm{Cd}(\mathrm{II})$ 
TABLE 3: Comparison of the parameters affecting the maximum adsorption efficiencies of different metal ions using different agricultural precursors between the two AC adsorbents.

\begin{tabular}{|c|c|c|c|c|c|c|c|}
\hline Adsorbent & Elements & $\mathrm{pH}$ & Dose $(\mathrm{g} / \mathrm{L})$ & Time $(\min )$ & $q_{e}(\mathrm{mg} / \mathrm{g})$ & Kinetics & Ref. \\
\hline Orange peel & $\mathrm{Cu}(\mathrm{II})$ & 5.8 & 0.5 & 120 & 25.8 & Pseudo $2^{\text {nd }}$ order & {$[12]$} \\
\hline Raw date pits & $\mathrm{Hg}(\mathrm{II})$ & 5 & 4 & 90 & $38.5-52.6$ & Pseudo $2^{\text {nd }}$ order & {$[48]$} \\
\hline Pomegranate peel & $\mathrm{Pb}(\mathrm{II})$ & $6-6.5$ & 1 & 60 & $22.5-27.5$ & Pseudo $2^{\text {nd }}$ order & {$[43]$} \\
\hline Date pits & $\begin{array}{l}\mathrm{Cd}(\mathrm{II}) \\
\mathrm{Cu}(\mathrm{II})\end{array}$ & 5.8 & 1 & 75 & $7.4-33.44$ & Pseudo $2^{\text {nd }}$ order & {$[46]$} \\
\hline Pomegranate peel & $\mathrm{Pb}(\mathrm{II})$ & 6.5 & 1 & 80 & 18.52 & Pseudo $1^{\text {st }}$ order & [44] \\
\hline Phragmites australis & $\mathrm{Cd}(\mathrm{II})$ & 6 & 0.5 & 30 & $5.8-7.8$ & $*$ & [49] \\
\hline Plum stone & $\mathrm{Pb}(\mathrm{II})$ & 5.5 & 0.5 & 90 & $48.3-80.6$ & Pseudo $2^{\text {nd }}$ order & {$[50]$} \\
\hline Banana peel & $\mathrm{Cd}(\mathrm{II})$ & 3 & 30 & 20 & 5.7 & ${ }^{*}$ & {$[51]$} \\
\hline Modified orange peel & $\mathrm{Cu}(\mathrm{II})$ & 5 & 2 & 180 & 28.9 & $*$ & {$[52]$} \\
\hline Pomelo peel & $\mathrm{Cu}(\mathrm{II})$ & 4 & 5 & 60 & 34.84 & $*$ & {$[53]$} \\
\hline Mango peel & $\mathrm{Ni}(\mathrm{II})$ & $4-6$ & 2 & 80 & 28.21 & $*$ & {$[54]$} \\
\hline $\begin{array}{l}\text { Date pits } \\
\text { Pomegranate peel }\end{array}$ & $\begin{array}{l}\mathrm{Pb}(\mathrm{II}) \\
\mathrm{Cd}(\mathrm{II})\end{array}$ & $6-6.5$ & $\begin{array}{c}1 \\
0.5\end{array}$ & 90 & $53.8-68.6$ & Pseudo $2^{\text {nd }}$ order & Recent data \\
\hline
\end{tabular}

${ }^{*}$ Not available.
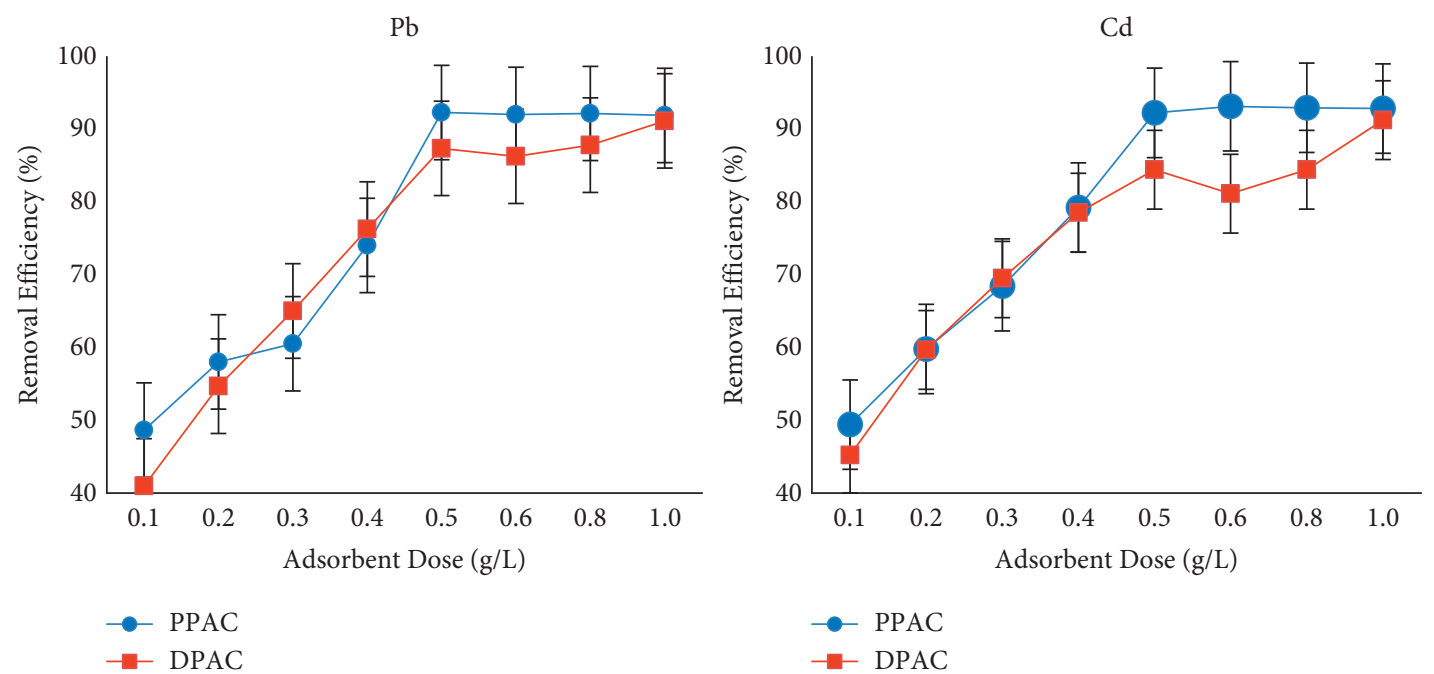

Figure 8: Effect of adsorbent dose on the adsorption of $\mathrm{Pb}(\mathrm{II})$ and $\mathrm{Cd}(\mathrm{II})(\mathrm{pH}=6$, metal concentration $=100 \mathrm{mg} / \mathrm{L}$, and contact time $=90 \mathrm{~min})$.
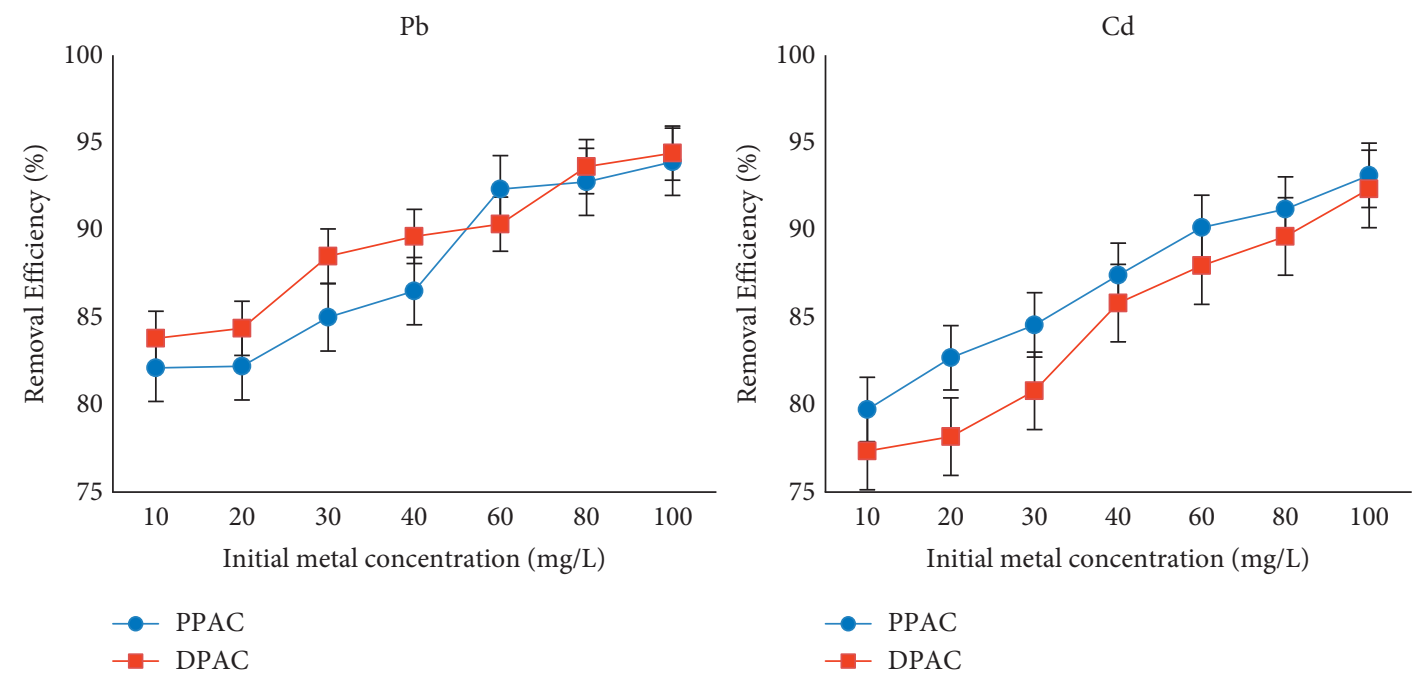

Figure 9: Effect of initial metal concentration on the adsorption of $\mathrm{Pb}(\mathrm{II})$ and $\mathrm{Cd}(\mathrm{II})(\mathrm{pH}=6$, contact time $=90 \mathrm{~min}, \mathrm{dose}$ of $\mathrm{DPAC}=1 \mathrm{~g} / \mathrm{L}$, and dose of PPAC $=0.5 \mathrm{~g} / \mathrm{L}$ ). 
concentrations. The maximum removal efficiencies of $\mathrm{Pb}$ (II) and $\mathrm{Cd}(\mathrm{II})$ were $93.9 \%$ and $94.4 \%$ for DPAC and $93.1 \%$ and $92.3 \%$ for PPAC at $100 \mathrm{mg} / \mathrm{L}$ metal ion concentrations, respectively. Slight variations in the removal efficiency were observed for both adsorbents.

\section{Adsorption Equilibrium Isotherms}

The equilibrium between the adsorbent (solid phase) and adsorbate (liquid phase) was described by using adsorption isotherm models. The reaction system reached equilibrium when a balance between the concentrations of the adsorbate and adsorbent was achieved. The calculated constants of an adsorption isotherm measured the surface properties' affinities of the DPAC and PPAC adsorbents for $\mathrm{Pb}(\mathrm{II})$ and $\mathrm{Cd}(\mathrm{II})$ ions. The Langmuir and Freundlich isotherm models were used to illustrate the adsorption process.

4.1. Langmuir Isotherm Model. The isotherm models of Langmuir postulate that adsorption occurred as a homogeneous monomolecular layer onto the adsorbent's surface.

The Langmuir model is expressed by Langmuir equation as follows [55]:

$$
\frac{1}{q_{e}}=\frac{1}{q_{\max }}+\frac{1}{b q_{\max }} \cdot \frac{1}{c_{e}},
$$

where $q_{\max }\left(\mathrm{mg}^{-1} \mathrm{~g}^{-1}\right)$ is the maximum uptake of sorbate, $q_{e}$ is the equilibrium concentration of sorbate $\left(\mathrm{mg} \cdot \mathrm{g}^{-1}\right), c_{e}$ $\left(\mathrm{mg} \cdot \mathrm{L}^{-1}\right)$ is the metal concentration at equilibrium, and $b$ $\left(\mathrm{L} \cdot \mathrm{mg}^{-1}\right)$ is the Langmuir constant.

The calculated equilibrium constants for the $\mathrm{Pb}(\mathrm{II})$ and Cd(II) adsorptions onto the surface of the two adsorbents showed good fits to the Langmuir isotherm model with $R^{2}>0.95$ (Table 4, Figure 10), so homogeneous monolayer adsorptions of $\mathrm{Pb}(\mathrm{II})$ and $\mathrm{Cd}(\mathrm{II})$ appeared to best explain this adsorption process. Furthermore, the adsorption efficiencies for both $\mathrm{Pb}(\mathrm{II})$ and $\mathrm{Cd}(\mathrm{II})$ were higher $\left(q_{\max }=68.6\right.$ and $53.8 \mathrm{mg} / \mathrm{g}$ for $\mathrm{Pb}(\mathrm{II})$ and $\mathrm{Cd}(\mathrm{II})$ ) for PPAC than for DPAC $\left(q_{\max }=34.18\right.$ and $32.90 \mathrm{mg} / \mathrm{g}$ for $\mathrm{Pb}(\mathrm{II})$ and $\left.\mathrm{Cd}(\mathrm{II})\right)$. The Langmuir dimensionless separation constant $\left(R_{L}\right)$ that defines the affinity sorbate-sorbent affinity is an important feature of the adsorption isotherm. $R_{L}$ is expressed in equation (5) [56].

$$
R_{L}=\frac{1}{1+b C_{i}},
$$

where $C_{i}$ is the initial metal ion concentration $(\mathrm{mg} / \mathrm{L})$ and $b$ is the Langmuir constant. $R_{L}$ describes the type of Langmuir isotherm: irreversible if $R_{L}=0$, linear if $R_{L}=1$, unfavorable if $R_{L}>1$, or favorable if $0<R_{L}<1$ [57]. $R_{L}$ values for $\mathrm{Pb}$ (II) and Cd(II) adsorption onto the surface of PPAC and DPAC were found in the range of $0<R_{L}<1$, so a favorable adsorption was achieved (Table 4 ).

4.2. Freundlich Isotherm Model. The Freundlich isotherm model assumed that a heterogeneous adsorption took place on the adsorbent surface by the adsorbate molecules, so this model could be applied to both monolayer and multilayer adsorption. The Freundlich isotherm model is described by equations (6) and (7) [58].

$$
q_{e}=K_{f} C_{e}^{1 / n}
$$

$$
\log q_{e}=\log K_{f}+\frac{1}{n} \log C_{e},
$$

where $q_{e}$ is the amount of metal adsorbed by the adsorbent ( $\mathrm{mg} / \mathrm{g}), C_{e}$ is the equilibrium adsorbate concentration in $\mathrm{mg} /$ $\mathrm{L}, K_{f}$ is the adsorbent capacity, and $n$ is the adsorption intensity determined from the linear plot.

Figure 11 shows the linear relationship between $\log q_{e}$ and $\log C_{t}$ at constant temperature. The Freundlich constants $\left(K_{f}, n\right.$, and $\left.R^{2}\right)$ for both adsorbents are presented in Table 4. It is clear that the adsorption process does not follow the Freundlich model because the $R^{2}$ values are lower than those corresponding to those for the Langmuir model (Table 4$)$. The Freundlich intensity parameter $(1 / n)$ is a function of the strength of adsorption [59], and the values of $n$ were $<1$, which indicated that the adsorption of both metal ions was a chemical adsorption process [60].

\section{Kinetics Studies}

Kinetic adsorption is one of the most important parameters used to evaluate the adsorption process efficiency in addition to the transferring behavior of adsorbed molecules onto the adsorbents' surfaces [61]. Thus, pseudo-first-order and pseudo-second-order models were applied to investigate the kinetics of adsorption of $\mathrm{Pb}(\mathrm{II})$ and $\mathrm{Cd}(\mathrm{II})$ onto the surfaces of DPAC and PPAC.

5.1. Pseudo-First-Order Model. This model assumed that metal ions uptake is directly proportional to the difference between saturation levels and is expressed by the Lagergren [62] equation as follows:

$$
\log \left(q_{e}-q_{t}\right)=\log \left(q_{e}\right)-\frac{k_{1}}{0.203} t
$$

where $q_{t}$ is the concentration of adsorbed metal ions $(\mathrm{mg} / \mathrm{g})$ at time $t, q_{e}$ is the amount of adsorbed metal ions $(\mathrm{mg} / \mathrm{g})$ at equilibrium, and $k_{1}\left(\mathrm{~min}^{-1}\right)$ is the pseudo-first-order reaction constant.

5.2. Pseudo-Second-Order Model. This model supposes that chemical adsorption occurred since chemical bonds were formed between the adsorbent surface and adsorbate [63]. The pseudo-second-order model is expressed in equation (9) as follows:

$$
\frac{t}{q_{t}}=\frac{1}{k_{2} q_{e}^{2}}+\frac{1}{q_{e}} t
$$

where $q_{t}$ is the concentration of adsorbed metal ions $(\mathrm{mg} / \mathrm{g})$ at time $t, q_{e}$ is the amount of adsorbed metal ions $(\mathrm{mg} / \mathrm{g})$ at equilibrium, and $k_{2}\left(\mathrm{mg} / \mathrm{g} \cdot \mathrm{min}^{-1}\right)$ is the pseudo-secondorder reaction constant. 
TABLE 4: Constants of Langmuir and Freundlich isotherms for $\mathrm{Pb}(\mathrm{II})$ and $\mathrm{Cd}(\mathrm{II})$ adsorption by DPAC and PPAC adsorbents.

\begin{tabular}{|c|c|c|c|c|c|c|c|c|c|c|c|c|c|c|}
\hline & \multicolumn{8}{|c|}{ Langmuir } & \multicolumn{6}{|c|}{ Freundlich } \\
\hline & \multicolumn{4}{|c|}{ PPAC } & \multicolumn{4}{|c|}{ DPAC } & \multicolumn{3}{|c|}{ PPAC } & \multicolumn{3}{|c|}{ DPAC } \\
\hline & $b$ & $q_{\max }$ & $R_{L}$ & $R^{2}$ & $b$ & $q_{\max }$ & $R_{L}$ & $R^{2}$ & $K_{f}$ & $n$ & $R^{2}$ & $K_{f}$ & $n$ & $R^{2}$ \\
\hline $\mathrm{Pb}(\mathrm{II})$ & 0.01 & 68.60 & 0.50 & 0.95 & 0.01 & 34.18 & 0.45 & 0.98 & 1.08 & 0.54 & 0.82 & 1.13 & 0.55 & 0.91 \\
\hline $\mathrm{Cd}(\mathrm{II})$ & 0.01 & 53.80 & 0.42 & 0.97 & 0.01 & 32.90 & 0.55 & 0.98 & 1.06 & 0.53 & 0.97 & 1.22 & 0.54 & 0.90 \\
\hline
\end{tabular}
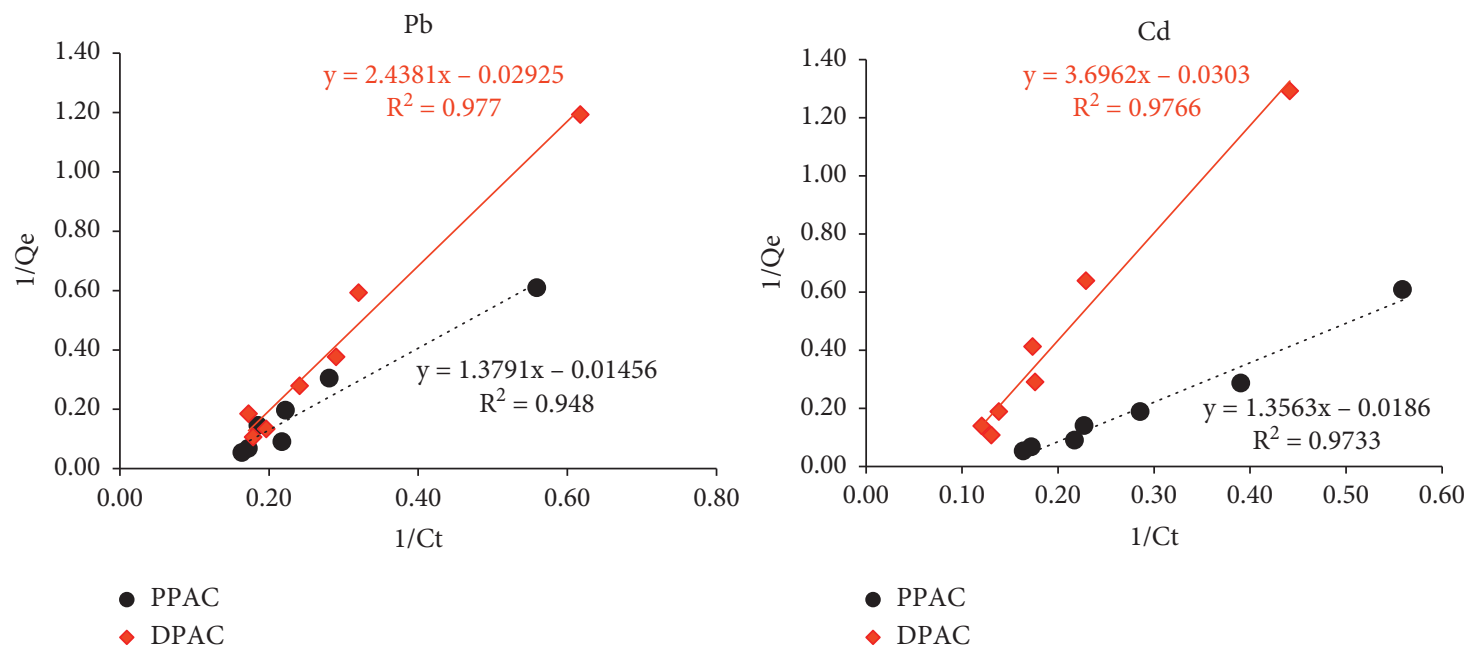

FIgURe 10: Langmuir isotherm plot for adsorption of $\mathrm{Pb}(\mathrm{II})$ and $\mathrm{Cd}(\mathrm{II})$ ions by the $\mathrm{DPAC}$ and PPAC adsorbents.
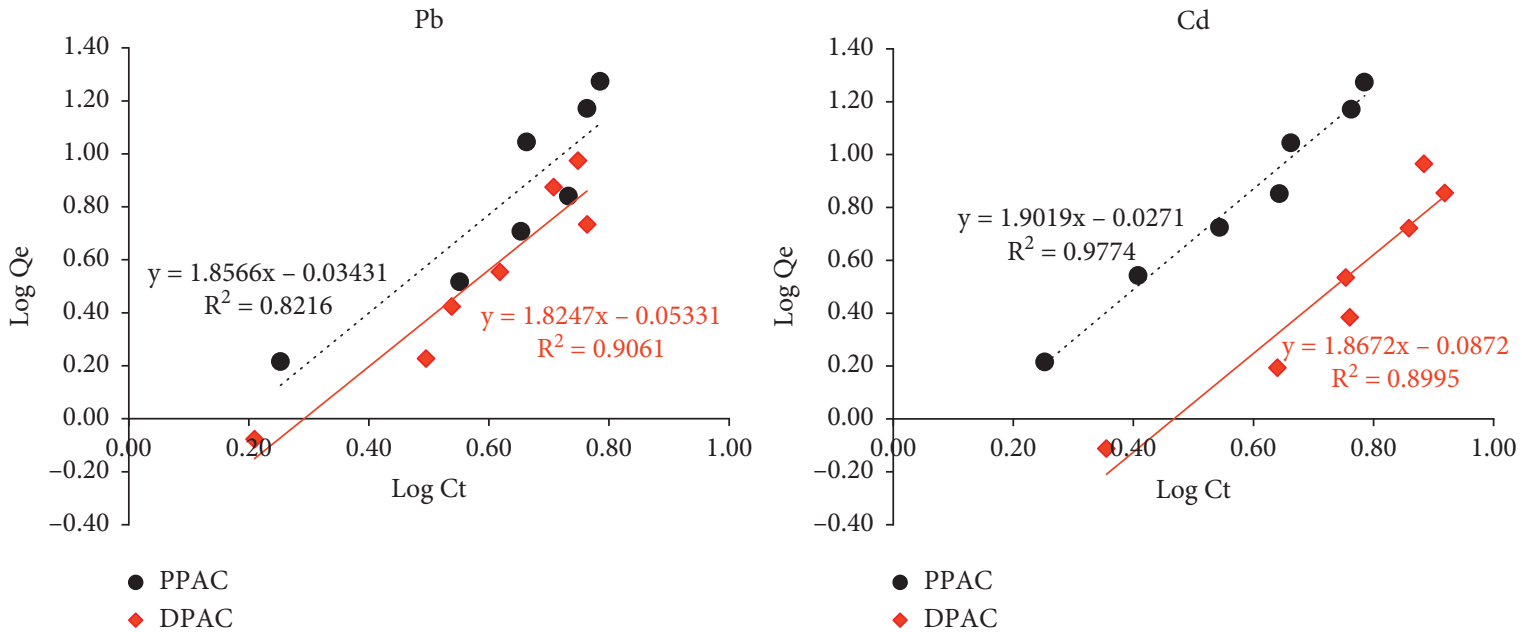

Figure 11: Freundlich isotherm plot for adsorption of $\mathrm{Pb}(\mathrm{II})$ and $\mathrm{Cd}(\mathrm{II})$ ions by the $\mathrm{DPAC}$ and PPAC adsorbents.

The linear plots and kinetic constants of the pseudofirst- and pseudo-second-order reactions are presented in Table 5 and Figures 12 and 13. Notably, all kinetics constants were higher for the pseudo-second-order reaction than for the pseudo-first-order reaction, and the recorded $q_{e}$ ranged from 12.0 to $22.37 \mathrm{mg} / \mathrm{g}$, with $R^{2}=0.99$. Therefore, the $\mathrm{Pb}(\mathrm{II})$ and $\mathrm{Cd}(\mathrm{II})$ adsorption processes followed the pseudo-second-order kinetic model. Our findings are concordant with those obtained by Al-Qahtani et al. [64] who reported that the pseudosecond-order model reflected the adsorption of $\mathrm{Ni}(\mathrm{II})$,
$\mathrm{Pb}(\mathrm{II})$, and $\mathrm{Cu}(\mathrm{II})$ onto the surface of some extremophilic cyanobacterial mats. In addition, several studies proved that the pseudo-second-order kinetic model fit the data well for the adsorption processes of $\mathrm{Pb}(\mathrm{II}), \mathrm{Cd}(\mathrm{II})$, and $\mathrm{Hg}$ onto the surfaces of different adsorbents $[27,35,41,65]$.

The proposed adsorption mechanism onto the PPAC and DPAC is demonstrated in Figure 14. Many research studies have reported that the dominant mechanism is ion exchange in the sorption of heavy metals by natural materials. 
TABLE 5: Pseudo-first-order and pseudo-second-order reaction constants for adsorption of $\mathrm{Pb}(\mathrm{II})$ and $\mathrm{Cd}(\mathrm{II})$ onto the surface of PPAC and DPAC adsorbents.

\begin{tabular}{|c|c|c|c|c|c|c|c|c|c|c|c|c|}
\hline & \multicolumn{6}{|c|}{ Pseudo-first-order reaction } & \multicolumn{6}{|c|}{ Pseudo-second-order reaction } \\
\hline & \multicolumn{3}{|c|}{ PPAC } & \multicolumn{3}{|c|}{ DPAC } & \multicolumn{3}{|c|}{ PPAC } & \multicolumn{3}{|c|}{ DPAC } \\
\hline & $q_{e}$ & $K_{1}$ & $R^{2}$ & $q_{e}$ & $K_{1}$ & $R^{2}$ & $q_{e}$ & $K_{2}$ & $R^{2}$ & $q_{e}$ & $K_{2}$ & $R^{2}$ \\
\hline $\mathrm{Pb}(\mathrm{II})$ & 6.24 & 0.029 & 0.46 & 12.88 & 0.035 & 0.87 & 20.28 & 0.003 & 0.99 & 13.21 & 0.001 & 0.91 \\
\hline Cd(II) & 13.15 & 0.033 & 0.67 & 8.50 & 0.038 & 0.59 & 22.37 & 0.002 & 0.97 & 12.00 & 0.002 & 0.94 \\
\hline
\end{tabular}
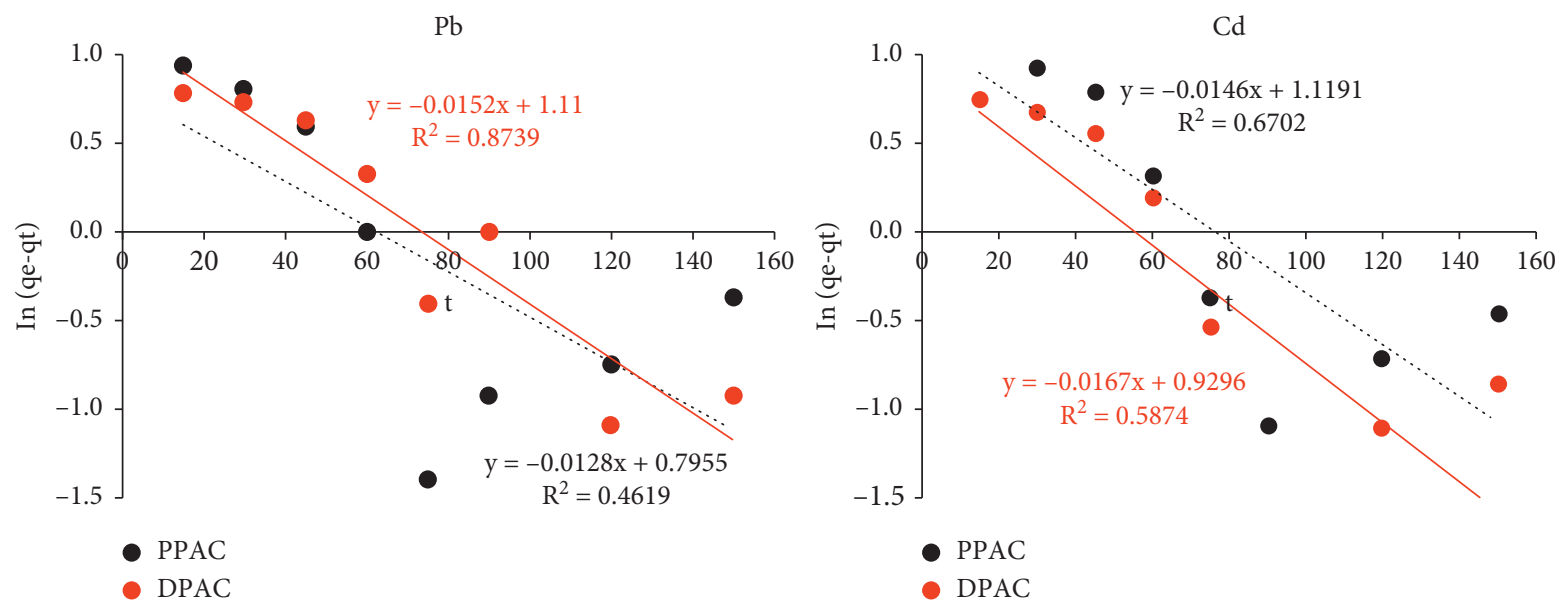

Figure 12: Pseudo-first-order reaction plots for $\mathrm{Pb}(\mathrm{II})$ and $\mathrm{Cd}(\mathrm{II})$ adsorption onto DPAC and PPAC.

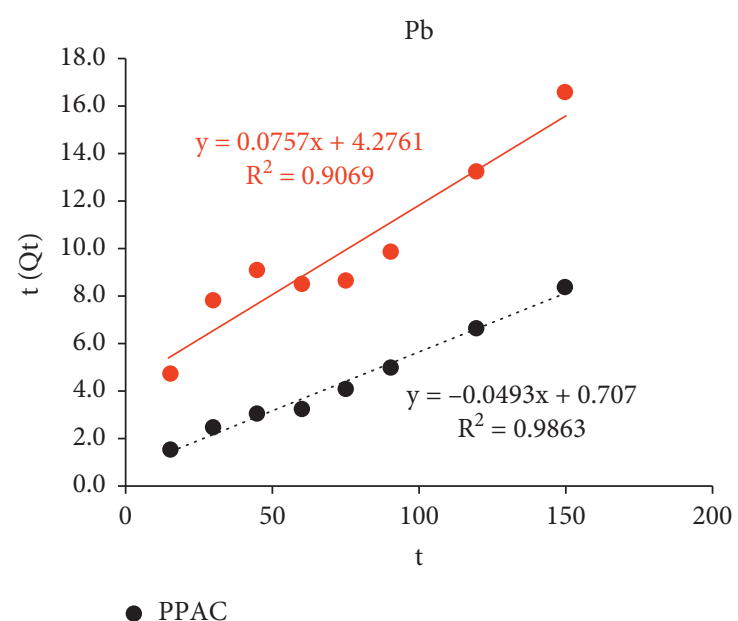

- DPAC

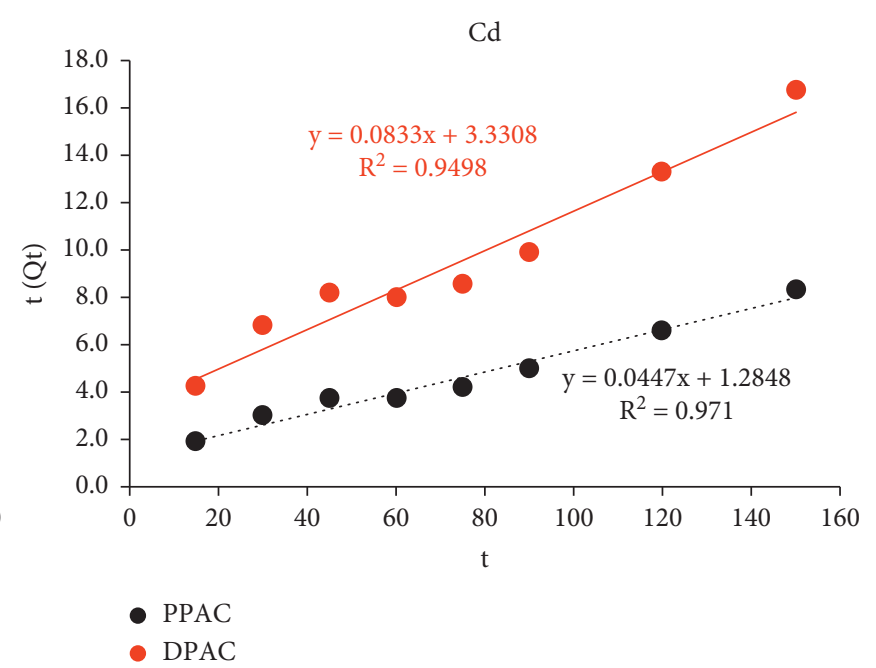

DPAC

Figure 13: Pseudo-second-order reaction plots for $\mathrm{Pb}(\mathrm{II})$ and $\mathrm{Cd}(\mathrm{II})$ adsorption onto DPAC and PPAC. 

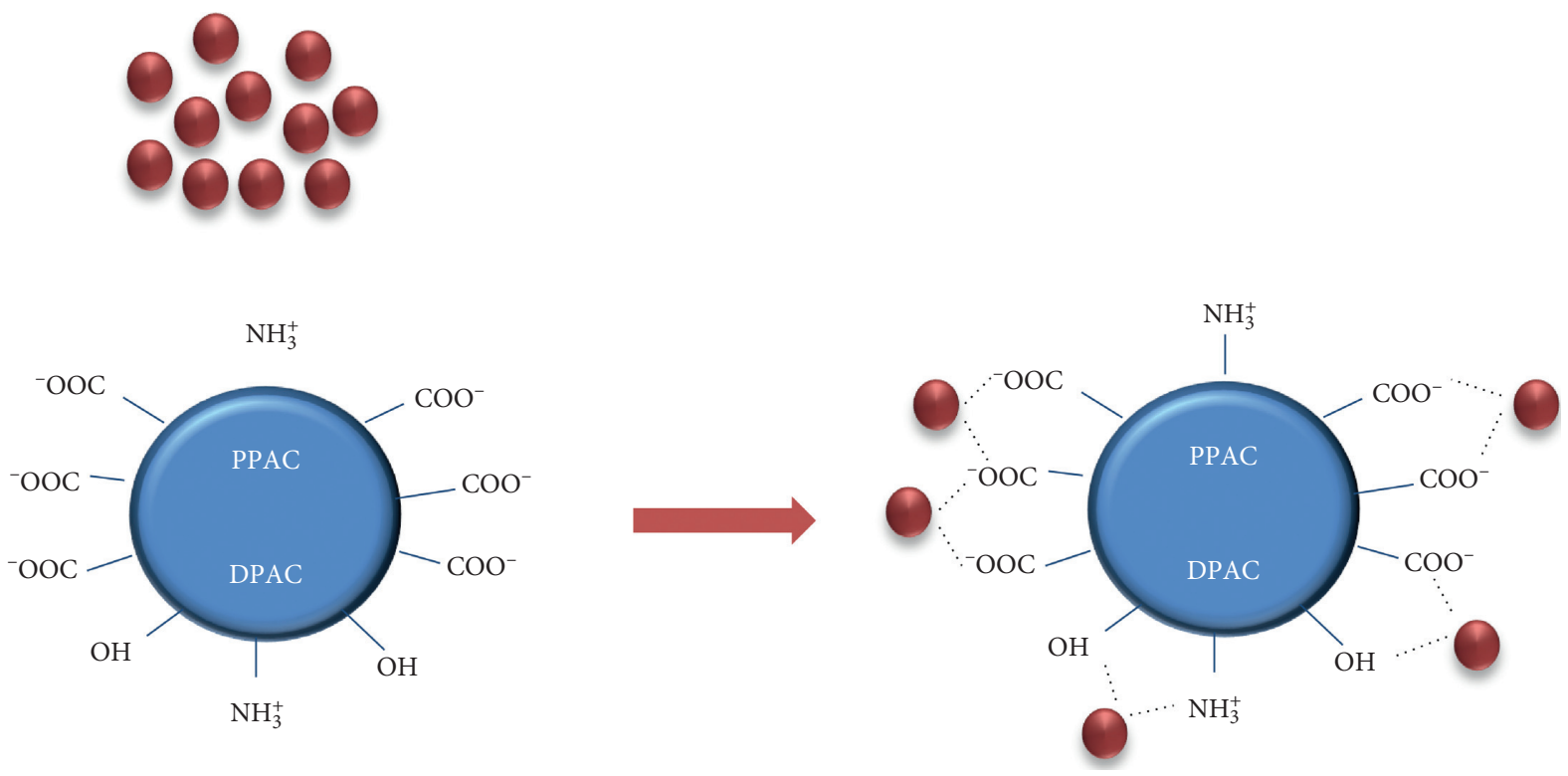

FIGURE 14: Schematic diagram illustrating the proposed mechanisms for heavy metals' adsorption onto DPAC and PPAC.

\section{Conclusion}

Removal of different inorganic or organic pollutants by adsorption onto the surface of agricultural wastes has the advantages such as low cost, high efficiency and selectivity, environmental savings, and minimal levels of toxicity. Raw PPs and DPs were used as primary precursors for carbonization and chemical activation with $\mathrm{H}_{3} \mathrm{PO}_{4}(60 \%)$ and $\mathrm{ZnCl}_{2}$ for use as biosorbents (adsorbents) to remove Cd(II) and $\mathrm{Pb}$ (II) from their aqueous solutions. Factors found to affect the adsorption process were solution $\mathrm{pH}$, contact time, initial metal ion concentrations, adsorbent quantity, $\mathrm{pH}$ (with maximum removal capacities of $\mathrm{Cd}(\mathrm{II})$ and $\mathrm{Pb}(\mathrm{II})$ achieved at $\mathrm{pH}$ values from 6 to 6.5), and a contact time of $90 \mathrm{~min}$ for each adsorbent. The results showed that adsorption efficiency was higher for PPAC than for DPAC. The recorded $\mathrm{Pb}(\mathrm{II})$ and $\mathrm{Cd}(\mathrm{II}) q_{\max }$ values were 68.6 and $53.8 \mathrm{mg} / \mathrm{g}$ for PPAC and 34.18 and $32.90 \mathrm{mg} / \mathrm{g}$ for DPAC, respectively. The adsorption process data fit the Langmuir isotherm model better than the Freundlich model. Kinetically, the adsorption reaction followed a pseudo-secondorder reaction model, with $q_{\mathrm{e}}$ ranging from 12.0 to $22.37 \mathrm{mg} /$ $\mathrm{g}$ and $R^{2}=0.99$.

\section{Data Availability}

All data are available within the manuscript.

\section{Conflicts of Interest}

The authors declare that they have no conflicts of interest.

\section{Acknowledgments}

This research project was supported by a grant from the Research Center of the Female Scientific and Medical Colleges, Deanship of Scientific Research, King Saud
University. The authors also thank the Deanship of Scientific Research and RSSU at King Saud University for their technical support.

\section{References}

[1] S. De Gisi, G. Lofrano, M. Grassi, and M. Notarnicola, "Characteristics and adsorption capacities of low-cost sorbents for wastewater treatment: a review," Sustainable Materials and Technologies, vol. 9, pp. 10-40, 2016.

[2] K. H. Vardhan, P. S. Kumar, and R. C. Panda, "A review on heavy metal pollution, toxicity and remedial measures: current trends and future perspectives," Journal of Molecular Liquids, vol. 290, Article ID 111197, 2019.

[3] M. H. Ali, A. E. M. Hussian, A. M. Abdel-Satar, M. E. Goher, A. Napiórkowska-Krzebietke, and A. M. A. El-Monem, "The isotherm and kinetic studies of the biosorption of heavy metals by non-living cells of Chlorella vulgaris," Journal of Elementology, vol. 21, no. 4, pp. 1263-1276, 2016.

[4] M. H. H. Ali, M. E. Goher, and A. D. G. Al-Afify, "Kinetics and adsorption isotherm studies of methylene blue photodegradation under UV irradiation using reduced graphene oxide- $\mathrm{TiO}_{2}$ nanocomposite in different wastewaters effluents," Egyptian Journal of Aquatic Biology and Fisheries, vol. 23, no. 1, pp. 253-263, 2019.

[5] K. M. Al-Qahtani, M. H. Ali, and A. D. Al-Afify, "Synthesis and use of $\mathrm{TiO}_{2} @ \mathrm{rGO}$ nanocomposites in photocatalytic removal of chromium and lead ions from wastewater," Journal of Elementology, vol. 25, no. 1, pp. 315-332, 2020.

[6] M. E. Goher, A. M. Abdel-Satar, M. H. Ali, A. E. Hussian, and A. Napiórkowska-Krzebietke, "Biosorption of some toxic metals from aqueous solution using non-living algal cells of Chlorella vulgaris," Journal of Elementology, vol. 21, no. 3, pp. 703-714, 2016.

[7] Q. Yang, M. Gao, and W. Zang, "Comparative study of 2, 4, 6trichlorophenol adsorption by montmorillonites functionalized with surfactants differing in the number of head group and alkyl chain," Colloids and Surfaces A: Physicochemical and Engineering Aspects, vol. 520, pp. 805-816, 2017. 
[8] M. H. H. Ali, M. S. Abd Elkarim, S. A. Haroun, and K. M. Attwa, "Bioremediation of $\mathrm{Fe}, \mathrm{Zn}$ and $\mathrm{Cd}$ ions from aqueous solution using died cells of cyanobacterial mats from extreme habitat, Siwa Oasis, Egypt," Egyptian Journal of Aquatic Biology and Fisheries, vol. 22, no. 5, pp. 511-522, 2019.

[9] A. Bhatnagar, M. Sillanpää, and A. Witek-Krowiak, "Agricultural waste peels as versatile biomass for water purificationa review," Chemical Engineering Journal, vol. 270, pp. 244271, 2015.

[10] I. Ali, M. Asim, and T. A. Khan, "Low cost adsorbents for the removal of organic pollutants from wastewater," Journal of Environmental Management, vol. 113, pp. 170-183, 2012.

[11] R. K. Gautam, A. Mudhoo, G. Lofrano, and M. C. Chattopadhyaya, "Biomass-derived biosorbents for metal ions sequestration: adsorbent modification and activation methods and adsorbent regeneration," Journal of Environmental Chemical Engineering, vol. 2, no. 1, pp. 239259, 2014.

[12] M. H. Ali and A. M. Abdel-Satar, "Removal of some heavy metals from aqueous solutions using natural wastes orange peel activated carbon," IJRDO-Journal of Applied Science, vol. 3, no. 3, pp. 13-30, 2017.

[13] S. Singh, V. Kumar, S. Datta et al., "Current advancement and future prospect of biosorbents for bioremediation," The Science of the Total Environment, vol. 709, Article ID 135895, 2019.

[14] R. Gayathri, K. P. Gopinath, P. Senthil Kumar, and S. Suganya, "Adsorption capability of surface-modified jujube seeds for $\mathrm{Cd}$ (II), Cu (II) and Ni (II) ions removal: mechanism, equilibrium, kinetic and thermodynamic analysis," Desalination and Water Treatment, vol. 140, pp. 268-282, 2019.

[15] G. Z. Kyzas, G. Bomis, R. I. Kosheleva et al., "Nanobubbles effect on heavy metal ions adsorption by activated carbon," Chemical Engineering Journal, vol. 356, pp. 91-97, 2019.

[16] K. O. Olayinka, B. I. Alo, and T. Adu, "Sorption of heavy metals from elecroplating effluents by low-cost adsorbents II: use of waste tea, coconut shell and coconut husk," Journal of Applied Sciences, vol. 7, no. 16, pp. 2307-2313, 2007.

[17] S. Ben-Ali, I. Jaouali, S. Souissi-Najar, and A. Ouederni, "Characterization and adsorption capacity of raw pomegranate peel biosorbent for copper removal," Journal of Cleaner Production, vol. 142, pp. 3809-3821, 2017.

[18] T. G. Chuah, A. Jumasiah, I. Azni, S. Katayon, and S. Y. Thomas Choong, "Rice husk as a potentially low-cost biosorbent for heavy metal and dye removal: an overview," Desalination, vol. 175, no. 3, pp. 305-316, 2005.

[19] M. Rahman, M. Adil, A. Yusof, Y. Kamaruzzaman, and R. Ansary, "Removal of heavy metal ions with acid activated carbons derived from oil palm and coconut shells," Materials, vol. 7, no. 5, pp. 3634-3650, 2014.

[20] F. S. Hashem, K. M. Al-Qahtani, F. F. Al-Fawzan, and M. Alshabanat, "Comparative study on activated carbon prepared from various fruit peels," International Journal of Innovative Research in Science, Engineering and Technology, vol. 5, no. 3, pp. 2750-1759, 2016.

[21] S. Abdić, M. Memić, E. Šabanović, J. Sulejmanović, and S. Begić, "Adsorptive removal of eight heavy metals from aqueous solution by unmodified and modified agricultural waste: tangerine peel," International Journal of Environmental Science and Technology, vol. 15, no. 12, pp. 2511-2518, 2018.

[22] I. Ali, S. Afshinb, Y. Poureshgh et al., "Green preparation of activated carbon from pomegranate peel coated with zerovalent iron nanoparticles (nZVI) and isotherm and kinetic studies of amoxicillin removal in water," Environmental
Science and Pollution Research, vol. 27, no. 29, pp. 3673236743, 2020.

[23] M. Khawaja, S. Mubarak, M. Zia-Ur-Rehman, A. A. Kazi, and A. Hamid, "Adsorption studies of pomegranate peel activated charcoal for nickel (II) ion," Journal of the Chilean Chemical Society, vol. 60, no. 4, pp. 2642-2645, 2015.

[24] S. Uçar, M. Erdem, T. Tay, and S. Karagöz, "Preparation and characterization of activated carbon produced from pomegranate seeds by $\mathrm{ZnCl} 2$ activation," Applied Surface Science, vol. 255, no. 21, pp. 8890-8896, 2009.

[25] G. Bharath, A. Hai, K. Rambabu et al., "Hybrid capacitive deionization of $\mathrm{NaCl}$ and toxic heavy metal ions using Faradic electrodes of silver nanospheres decorated pomegranate peelderived activated carbon," Environmental Research, vol. 197, Article ID 111110, 2021.

[26] M. A. Al-Omair and E. A. El-Sharkawy, "Removal of heavy metals via adsorption on activated carbon synthesized from solid wastes," Environmental Technology, vol. 28, no. 4, pp. 443-451, 2007.

[27] N. S. Awwad, A. A. El-Zahhar, A. M. Fouda, and H. A. Ibrahium, "Removal of heavy metal ions from ground and surface water samples using carbons derived from date pits," Journal of environmental chemical engineering, vol. 1, no. 3, pp. 416-423, 2013.

[28] R. Krishnamoorthy, B. Govindan, F. Banat, V. Sagadevan, M. Purushothaman, and P. L. Show, "Date pits activated carbon for divalent lead ions removal," Journal of Bioscience and Bioengineering, vol. 128, no. 1, pp. 88-97, 2019.

[29] S. Ben-Ali, A. Akermi, M. Mabrouk, and A. Ouederni, "Optimization of extraction process and chemical characterization of pomegranate peel extract," Chemical Papers, vol. 72, no. 8, pp. 2087-2100, 2018.

[30] M. Belhachemi, R. V. R. A. Rios, F. Addoun, J. SilvestreAlbero, A. Sepúlveda-Escribano, and F. Rodríguez-Reinoso, "Preparation of activated carbon from date pits: effect of the activation agent and liquid phase oxidation," Journal of Analytical and Applied Pyrolysis, vol. 86, no. 1, pp. 168-172, 2009.

[31] C. Bouchelta, M. S. Medjram, O. Bertrand, and J.-P. Bellat, "Preparation and characterization of activated carbon from date stones by physical activation with steam," Journal of Analytical and Applied Pyrolysis, vol. 82, no. 1, pp. 70-77, 2008.

[32] K. S. K. Reddy, A. Al Shoaibi, and C. Srinivasakannan, "Preparation of porous carbon from date palm seeds and process optimization," International Journal of Environmental Science and Technology, vol. 12, no. 3, pp. 959-966, 2015.

[33] R. Nasser, M. Salem, S. Hiziroglu et al., "Chemical analysis of different parts of date palm (Phoenix dactylifera L.) using ultimate, proximate and thermo-gravimetric techniques for energy production," Energies, vol. 9, no. 5, p. 374, 2016.

[34] X. Xia, H. Li, D. Cao et al., "Characterization of a NAC transcription factor involved in the regulation of pomegranate seed hardness (Punica granatum L.)," Plant Physiology and Biochemistry, vol. 139, pp. 379-388, 2019.

[35] E. Elaiyappillai, R. Srinivasan, Y. Johnbosco et al., "Low cost activated carbon derived from Cucumis melo fruit peel for electrochemical supercapacitor application," Applied Surface Science, vol. 486, pp. 527-538, 2019.

[36] Z. Zhang, I. M. O’Hara, G. A. Kent, and W. O. S. Doherty, "Comparative study on adsorption of two cationic dyes by milled sugarcane bagasse," Industrial Crops and Products, vol. 42, pp. 41-49, 2013. 
[37] H. Tounsadi, A. Khalidi, A. Machrouhi et al., "Highly efficient activated carbon from Glebionis coronaria L. biomass: optimization of preparation conditions and heavy metals removal using experimental design approach," Journal of Environmental Chemical Engineering, vol. 4, no. 4, pp. 4549-4564, 2016.

[38] G.-Z. Zhu, X.-L. Deng, M. Hou et al., "Comparative study on characterization and adsorption properties of activated carbons by phosphoric acid activation from corncob and its acid and alkaline hydrolysis residues," Fuel Processing Technology, vol. 144, pp. 255-261, 2016.

[39] L. A. Chuprov, P. G. Sennikov, K. G. Tokhadze, S. K. Ignatov, and O. Schrems, "High-resolution fourier-transform IR spectroscopic determination of impurities in silicon tetrafluoride and silane prepared from it," Inorganic Materials, vol. 42, no. 8, pp. 924-931, 2006.

[40] X. Yang, Y. Wan, Y. Zheng et al., "Surface functional groups of carbon-based adsorbents and their roles in the removal of heavy metals from aqueous solutions: a critical review," Chemical Engineering Journal, vol. 366, pp. 608-621, 2019.

[41] M. Abedi, M. H. Salmani, and S. A. Mozaffari, "Adsorption of $\mathrm{Cd}$ ions from aqueous solutions by iron modified pomegranate peel carbons: kinetic and thermodynamic studies," International Journal of Environmental Science and Technology, vol. 13, no. 8, pp. 2045-2056, 2016.

[42] Z. Manel, K. Y. Foo, S. N. Souissi, and A. Ouederni, "Preparation of pomegranate peels derived activated carbons by chemical and physio-chemical activation for the successive treatment of hazardous acetaminophen," in E-Proceedings of the 37th IAHR World Congress, Kuala Lumpur, Malaysia, August 2017.

[43] M. R. Moghadam, N. Nasirizadeh, Z. Dashti, and E. Babanezhad, "Removal of Fe (II) from aqueous solution using pomegranate peel carbon: equilibrium and kinetic studies," International Journal of Integrated Care, vol. 4, no. 1, p. 19, 2013.

[44] M. H. Salmani, M. Abedi, S. A. Mozaffari, and H. A. Sadeghian, "Modification of pomegranate waste with iron ions a green composite for removal of $\mathrm{Pb}$ from aqueous solution: equilibrium, thermodynamic and kinetic studies," AMB Express, vol. 7, no. 1, p. 225, 2017.

[45] A. Y. Lee, S. F. Lim, S. N. Chua, K. Sanaullah, R. Baini, and M. O. Abdullah, "Adsorption equilibrium for heavy metal divalent ions $\left(\mathrm{Cu}^{2+}, \mathrm{Zn}^{2+}\right.$, and $\left.\mathrm{Cd}^{2+}\right)$ into zirconium-based ferromagnetic sorbent," Advances in Materials Science and Engineering, vol. 2017, Article ID 1210673, 13 pages, 2017.

[46] N. M. Hilal, I. A. Ahmed, and R. E. El-Sayed, "Activated and nonactivated date pits adsorbents for the removal of copper (II) and cadmium (II) from aqueous solutions," International Scholarly Research Notices, vol. 2012, Article ID 985853, 11 pages, 2012.

[47] K. Al-Balushi, S. Revanuru, and S. R. Sajjala, "Preparation of activated carbon from date seeds and evaluation of its applications," Journal of Mechanical and Civil Engineering, vol. 15, 2018.

[48] A. Rezgui, E. Guibal, and T. Boubakera, "Sorption of Hg (II) and $\mathrm{Zn}$ (II) ions using lignocellulosic sorbent (date pits)," Canadian Journal of Chemical Engineering, vol. 95, no. 4, pp. 775-782, 2017.

[49] M. Farasati, S. Haghighi, and S. Boroun, "Cd removal from aqueous solution using agricultural wastes," Desalin Water Treat, vol. 57, no. 24, pp. 11164-11172, 2015.

[50] S. Parlayıcı and E. Pehlivan, "Removal of metals by Fe3O4 loaded activated carbon prepared from plum stone (Prunus nigra): kinetics and modelling study," Powder Technology, vol. 317, pp. 23-30, 2017.

[51] J. Anwar, U. Shafique, Z. Waheed-uz-Zaman, M. Salman, A. Dar, and S. Anwar, "Removal of Pb (II) and Cd (II) from water by adsorption on peels of banana," Bioresource Technology, vol. 101, no. 6, pp. 1752-1755, 2010.

[52] N. Feng, X. Guo, and S. Liang, "Adsorption study of copper (II) by chemically modified orange peel," Journal of Hazardous Materials, vol. 164, no. 2-3, pp. 1286-1292, 2009.

[53] P. Tasaso, "Adsorption of copper using pomelo peel and depectinated pomelo peel," Journal of Clean Energy Technologies, vol. 2, pp. 154-157, 2014.

[54] W. H. Zou, L. Zhao, and L. Zhu, "Efficient uranium (VI) biosorption on grapefruit peel: kinetic study and thermodynamic parameters," Journal of Radioanalytical and Nuclear Chemistry, vol. 292, no. 3, pp. 1303-1315, 2012.

[55] I. Langmuir, "The constitution and fundamental properties of solids and liquids. Part I. Solids," Journal of the American Chemical Society, vol. 38, no. 2, pp. 2221-2295, 1916.

[56] P. K. Malik, "Use of activated carbons prepared from sawdust and rice-husk for adsorption of acid dyes: a case study of acid yellow 36," Dyes and Pigments, vol. 56, no. 3, pp. 239-249, 2003.

[57] G. McKay, H. S. Blair, and J. R. Gardner, "Adsorption of dyes on chitin. I. Equilibrium studies," Journal of Applied Polymer Science, vol. 27, no. 8, pp. 3043-3057, 1982.

[58] M. H. Kalavathy, T. Karthikeyan, S. Rajgopal, and L. R. Miranda, "Kinetic and isotherm studies of $\mathrm{Cu}$ (II) adsorption onto $\mathrm{H}_{3} \mathrm{PO}_{4}$-activated rubber wood sawdust," Journal of Colloid and Interface Science, vol. 292, no. 2, pp. 354-362, 2005.

[59] E. Voudrias, K. Fytianos, and E. Bozani, "Sorption-desorption isotherms of dyes from aqueous solutions and wastewaters with different sorbent materials," Global Nest Journal, vol. 4, no. 1, pp. 75-83, 2002.

[60] M. B. Desta, "Batch sorption experiments: Langmuir and Freundlich isotherm studies for the adsorption of textile metal ions onto teff straw (Eragrostis tef) agricultural waste," Journal of Thermodynamics, vol. 20, pp. 375-380, 2013.

[61] W. A. Al-Onazi and M. H. H. Ali, "Synthesis and characterization of cerium oxide hybrid with chitosan nanoparticles for enhancing the photodegradation of Congo Red dye," Journal of Materials Science: Materials in Electronics, vol. 32, no. 9, pp. 12017-12030, 2021.

[62] S. K. Lagergren, "About the theory of so-called adsorption of soluble substances," Svenska Vetenskapsakademiens Handingar, vol. 24, pp. 1-39, 1898.

[63] E. Bernard, A. Jimoh, and J. Odigure, "Heavy metals removal from industrial wastewater by activated carbon prepared from coconut shell," Research Journal of Chemical Sciences, vol. 3, pp. 3-9, 2013.

[64] K. M. Al-Qahtani, M. H. Ali, M. S. Abdelkarim, and A. D. AlAfify, "Efficiency of extremophilic microbial mats for removing $\mathrm{Pb}$ (II), $\mathrm{Cu}$ (II), and $\mathrm{Ni}$ (II) ions from aqueous solutions," Environmental Science and Pollution Research, pp. 1-14, 2021.

[65] B. Abbar, A. Alem, S. Marcotte et al., "Experimental investigation on removal of heavy metals $(\mathrm{Cu} 2+, \mathrm{Pb} 2+$, and $\mathrm{Zn} 2+)$ from aqueous solution by flax fibres," Process Safety and Environmental Protection, vol. 109, pp. 639-647, 2017. 